\title{
FATAL POISONING BY ALCOHOL AND HEROIN*
}

\author{
Davorka SUTLOVIĆ and Marija DEFINIS-GOJANOVIĆ \\ Department of Pathology and Forensic Medicine, Split University Hospital and School of \\ Medicine, Split, Croatia \\ Received in September 2006 \\ Accepted in April 2007
}

\begin{abstract}
Drug abuse with alcohol consumption have been on the rise in Split-Dalmatian County for a while now. This article reports two separate cases with three deaths due to fatal combinations of heroin and alcohol. The first case of poisoning is related to a young couple, a 30-year-old man and a 28-year-old woman, who were found dead in a car, surrounded by cans of a variety alcoholic drinks. Two needles were found beside the bodies as well. The victims were registered drug abusers who had been in withdrawal programs. The second case was a 29-year-old man who was found dead in a house. Three fresh injection marks were visible on his right arm, and two needles were near his body. He was not known as a drug addict, but he had tried to commit suicide recently.

Carboxyhaemoglobin was found in blood samples of both victims from the first case. The concentration was $25 \%$ and that could contribute to their death. In both described cases blood alcohol concentration was higher then $1.60 \mathrm{~g} \mathrm{~kg}^{-1}$. Toxicology tests were positive for heroin, meconin, acetaminophen, 6-acetylmorphine, codeine, noscapine and papaverine. Ethanol, being a respiratory depressant, combined with morphine drastically increases the risk of rapid death due to respiration failure.
\end{abstract}

KEY WORDS: death, fatal intoxication, intravenous injection, toxicology

Recent years have seen an increase in illicit drug consumption in Croatia. In Split-Dalmatian County the number of drug addicts and of fatal poisonings has increased since the beginning of the 1990s (1). The most common poisonings are by heroin (2).

Morphine is an opiate analgesic which itself is abused, but is more frequently found as a metabolite of heroin (diacetyl morphine). After administration, heroin rapidly hydrolyses in whole blood to 6monoacetylmorphine (6-MAM) with a half-life from less than 20 min to $\sim 3$ min after parenteral administration. This process probably continues after death. Morphine is amphoteric and moderately lipidsoluble (3). Although fatal outcome due to injection of heroin is widely recognised and documented, post-mortem morphine concentrations show large individual variations (4). These could be explained by differences in samples used, differences in tolerance and the time interval between injection and death. Victims may be influenced by other drugs, and a negative correlation between morphine concentration and alcohol concentration has been shown in both unconscious and deceased drug addicts, indicating an additive effect of alcohol to heroin toxicity (4).

The objective of this study was to find out whether or not toxicological analysis of multiple samples could be of any support in determining the cause of death.

\section{MATERIALS AND METHODS}

In order to establish drug distribution, multiple samples were collected at autopsy and stored at 
$4{ }^{\circ} \mathrm{C}$ until analysis. All solvents and chemicals were analytical-grade-purity products of Merck Darmstadt, Germany. Solid-phase extraction was performed using Amberlite XAD-2, polyaromatic adsorbent resin (Supelco; SIGMA ALDRICH, Taufkirchen, Germany) (5). Pentafluoropropionic acid anhydrides (PFPA), Bis (trimethylsilyl) trifluoroacetamide (BSTFA) with $1 \%$ trimethylchlorosilane (TMCS) were obtained from Sigma Chemical Co. (St. Louis, MO, USA) and used in the analysis of drugs of abuse as a variety of derivatisation reagents (6).

The toxicological analysis was performed using a Shimadzu GC-2010 with ion trap mass spectrometer (mass selective detector, MSD). The chromatographic column was RTX-5MS (5 \% diphenyl + $95 \%$ dimethyl polysiloxane, $30 \mathrm{~m}$, and $0.25 \mathrm{~mm}$ i.d, with a film thick $0.25 \mu \mathrm{m})$. The initial column temperature of $90^{\circ} \mathrm{C}$ was held for $3 \mathrm{~min}$, then programmed to $270{ }^{\circ} \mathrm{C}$ at $20{ }^{\circ} \mathrm{C} / \mathrm{min}$, and held for $25 \mathrm{~min}$. Ultra-pure-grade helium was used as the carrier gas at a flow rate of about $1.5 \mathrm{~mL} \mathrm{~min}^{-1}$.

Blood-alcohol concentration (BAC) was measured using a Shimadzu 2010 gas chromatograph with headspace and flame ionisation detector (FID). TerButanol was used as standard solution.
Absorbancies at 541, 560 and $576 \mathrm{~nm}$ were measured by a spectrophotometer (Ultrospec 2000. Pharmacia Biotech (Biochrom) Ltd. Cambridge, England) to evaluate the amount of carboxyhemoglobin (COHb) (7).

\section{Case 1}

This winter, a young couple was found dead in a car in the suburb of Split. Syringes and cans of a variety of alcohol drinks were found around the bodies. Both man and the woman had a history of drug abuse, were registered by the police, and their families claimed that they were included in withdrawal programs at the time.

Blood, urine, tissue samples and syringes were collected for toxicological analysis. Routine screening for pharmaceutical drugs was negative. Heroin, meconin, papaverine and caffeine were found in both syringes. Meconin was found in all samples. Monoacetylmorphine was determined only in the woman's urine, bile and hair, while noscapine was detected in the man's hair (Tables 1-2). The man's blood alcohol mass fraction was $1.60 \mathrm{~g} \mathrm{~kg}^{-1}$ and urine alcohol mass fraction $2.93 \mathrm{~g} \mathrm{~kg}^{-1}$. The woman's blood alcohol mass fraction was $1.81 \mathrm{~g} \mathrm{~kg}^{-1}$ and urine

Table 1 Heroin and its distribution in the syringe, fluids and tissues of the woman in Case 1.

\begin{tabular}{|c|c|c|c|c|c|c|c|}
\hline $\begin{array}{l}\text { Sample } \\
\text { Compound }\end{array}$ & Syringe & Blood & Urine & Bile & Liver & Kidney & Hair \\
\hline Meconin & + & + & + & + & ND & ND & ND \\
\hline Caffeine & + & & + & + & + & + & + \\
\hline Heroin & + & ND & ND & ND & ND & ND & ND \\
\hline Monoacetylmorphine & ND & ND & + & + & ND & ND & + \\
\hline Papaverine & + & ND & ND & ND & ND & ND & ND \\
\hline
\end{tabular}

$+=$ positive

$N D=$ not determined

Table 2 Heroin and its distribution in the syringe, fluids and tissues of the man in Case 1.

\begin{tabular}{|c|c|c|c|c|c|c|c|}
\hline $\begin{array}{ll}\text { Sample } \\
\text { Compound }\end{array}$ & Syringe & Blood & Urine & Bile & Liver & Kidney & Hair \\
\hline Meconin & + & + & + & + & + & + & + \\
\hline Caffeine & + & ND & + & + & + & + & ND \\
\hline Heroin & + & ND & ND & ND & ND & ND & ND \\
\hline Noscapine & ND & ND & ND & ND & ND & ND & + \\
\hline Papaverine & + & ND & ND & ND & ND & ND & ND \\
\hline
\end{tabular}

$+=$ pozitive

$N D=$ not determined 
alcohol mass fraction $2.48 \mathrm{~g} \mathrm{~kg}^{-1}$ (Table 3). Blood concentration of $\mathrm{COHb}$ was $25 \%$ in both.

\section{Case 2}

A 29-year-old man was found dead in a house due to overdose. Allegedly, he had attempted suicide on an earlier occasion. Three fresh injection marks were found on his right arm, while two needles were near the body.

Toxicological testing of the syringe was positive for heroin, theophyline, meconin, acetaminophen, monoacetylmorphine, codeine, noscapine, papaverine and caffeine. Morphine concentration was much higher in tissue samples from the three injection marks than in other samples (according to the signal from GC/MS and sample weight) (Figure 1A). Meconin was found in blood, urine and bile samples, while codeine and monoacetylmorphine were found in blood (Figure 1 B-E and Tables 4-5). Blood alcohol mass fraction was $1.67 \mathrm{~g} \mathrm{~kg}^{-1}$ and urine alcohol mass fraction was $2.03 \mathrm{~g} \mathrm{~kg}^{-1}$ (Table 3).

\section{DISCUSSION}

Autopsy and histological findings in both presented cases pointed to drug poisoning as the cause of death, which was confirmed by toxicological analysis. Heroin (diacetylmorphine) is rapidly hydrolysed to 6-monoacetylmorphine which in turn is hydrolysed to morphine following intravenous administration in humans (8). Blood level of morphine depends on the route of administration, dose, body weight, time elapsed since the last dose, and individual pharmacokinetics (9). Heroin is mainly excreted in the urine as free and conjugated morphine. Our results strongly suggest that deaths had occurred shortly after injection, since no significant amounts of morphine had been excreted (except for the woman in Case 1). The reason for rapid death could have been the lack of heroin tolerance in injected persons (10).

The main mechanism of heroin-related death is respiratory depression. Ethanol itself can cause death by a combination of respiratory, cerebral and cardiac

Table 3 Blood and urine alcohol mass fraction $\left(\mathrm{g} \mathrm{kg}^{1}\right)$ in Case 1 and Case 2.

\begin{tabular}{llcc}
\hline \multirow{2}{*}{ Case } & & \multicolumn{2}{c}{ Alcohol $/ \mathbf{~ g ~ k g}^{-1}$} \\
& & Blood & Urine \\
\hline \multirow{2}{*}{ Case 1} & woman & 1.81 & 2.48 \\
& man & 1.60 & 2.93 \\
Case 2 & & 1.67 & 2.03 \\
\hline
\end{tabular}

Table 4 Heroin and its distribution in the syringe and tissue from injection marks in Case 2.

\begin{tabular}{|c|c|c|c|c|c|}
\hline Compound & Syringe1 & Syringe2 & $\begin{array}{l}\text { Tissue sample } \\
\text { from injection } \\
\text { mark } 1\end{array}$ & $\begin{array}{c}\text { Tissue sample } \\
\text { from injection } \\
\text { mark } 2\end{array}$ & $\begin{array}{c}\text { Tissue sample } \\
\text { from injection } \\
\text { mark } 3\end{array}$ \\
\hline Meconin & + & + & + & + & + \\
\hline Acetaminophen & + & + & + & + & + \\
\hline Caffeine & + & + & + & + & + \\
\hline Heroin & + & + & + & + & $+++\ddagger$ \\
\hline 3-acetylmorphine & + & + & ND & ND & ND \\
\hline 6-acetylmorphine & + & + & ND & ND & ND \\
\hline Codeine & + & + & + & + & + \\
\hline Noscapine & + & + & + & + & + \\
\hline Papaverine & + & + & + & + & + \\
\hline
\end{tabular}


Table 5 Heroin and its distribution in fluids and tissues in Case 2.

\begin{tabular}{|c|c|c|c|c|c|}
\hline $\begin{array}{ll}\text { Compound } & \text { Sample } \\
\end{array}$ & Blood & Urine & Bile & Liver & Kidney \\
\hline Meconin & + & + & + & ND & ND \\
\hline Acetaminophen & + & ND & ND & ND & ND \\
\hline Caffeine & + & + & + & + & + \\
\hline 3-acetylmorphine & + & ND & ND & ND & ND \\
\hline 6-acetylmorphine & + & ND & ND & ND & ND \\
\hline Codeine & + & ND & ND & ND & ND \\
\hline Noscapine & + & ND & ND & ND & ND \\
\hline
\end{tabular}

$+=$ positive

$N D=$ not determined

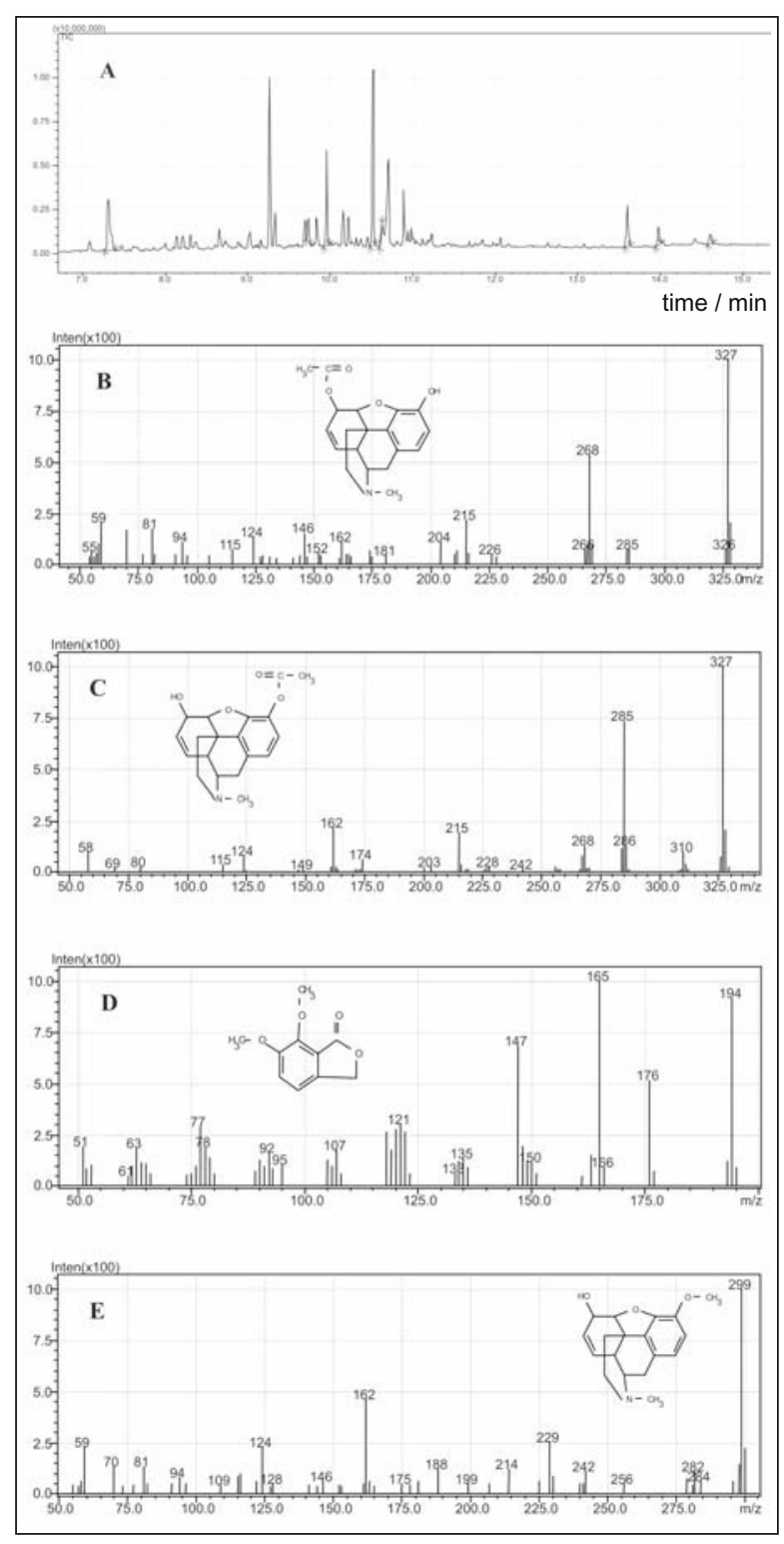

Figure 1 Total ion chromatogram of fresh injection marks (A) and characteristic spectra of 6-acetylmorphine(B), 3acetylmorphine $(C)$, meconin (D) and codeine $(E)$ depression (11). The effects of the consumption of opiates and alcohol together are therefore additive and drastically increase the risk of sudden or rapid death due to respiration failure. They also increase the risk of overdose in experienced drug abusers.

Blood morphine levels have been reported to be substantially lower in cases where alcohol is detected than in cases where it is not, although the clinical significance of this finding remains unclear (12-15). Darke S. and Zador D., reported similar findings by Chan et al., with mean blood morphine levels of $0.43 \mathrm{mg} \mathrm{L}^{-1}$ and $0.52 \mathrm{mg} \mathrm{L}^{-1}$, respectively, and observed that mean blood morphine level declined with increased blood alcohol (10).

Collection of tissue samples from injection marks and of control tissue samples has been recommended to establish the cause of death. Improved classification and reporting might include documenting the cause of death as, for instance, morphine only or combined effects of heroin and alcohol.

The $\mathrm{COHb}$ concentration of $25 \%$ found in blood of the young couple was sufficient for some clinical symptoms, but not for death (the lethal concentration is above $50 \%$ ), which suggests that this level could only contribute to the death (16). The couple was exposed to fumes from the car exhaust, but criminal investigation could not confirm their intention to commit suicide.

\section{REFERENCES}

1. Definis-Gojanović M, Kovačić Z. Deaths of drug addicts in Split. Arh Hig Rada Toksikol 1996;47:281-8.

2. Karačić V, Skender LJ, Brčić I, Bagarić A. Hair testing 
for drugs of abuse: A two-year experience. Arh Hig Rada Toksikol 2002;53:213-20.

3. Wexler P. Encyclopedia of Toxicology. $2^{\text {nd }}$ ed. Oxford: Elsevier LTD; 2005.

4. Druid H, Holmgren P. Fatal injections of heroin. Interpretation of toxicological findings in multiple specimens. Int J Legal Med 1999;112:62-6.

5. Moffat AC, Osselton MD, Widdop B. Clarke's analysis of drugs and poisons in pharmaceuticals, body fluids and postmortem material. $3^{\text {rd }}$ ed. London: Pharmaceutical Press; 2004.

6. Gerhards P, Bons U, Sawazki J, Szigan J, Wertmann A. GC/MS in Clinical Chemistry. Weinheim: WILEY-VCH Verlag GmbH.; 1999.

7. Contostavlos DL, Lichtenwalner M. A simple field test to detect elevated concentrations of carboxyhemoglobin in autopsy blood. J Clin Forensic Med 2003;10:7780.

8. Goodman and Gilman. The Pharmacological Basis of Therapeutics. $8^{\text {th }}$ ed. New York and Oxford: Pergamon Press; 1991.

9. Aderjan R, Hoemann S, Schmitt G, Skopp G. Morphine and morphine glucuronides in serum of heroin consumers and in heroin-related deaths determined by HPLC with native fluorescence detection. J Anal Toxicol 1995;19:163-8.

10. Darke S, Zador D. Fatal heroin "overdose": a review. Addiction 1996;91:1765-72.

11. Drummer $\mathrm{OH}$. The Forensic Pharmacology of Drugs of Abuse. London: Arnold, 2001.

12. Richards RG, Reed D, Cravey RH. Death from intravenously administered narcotics: a study of 114 cases. J Forensic Sci 1976;21:467-82.

13. Steentoft A, Worm K, Christenson H. Morphine concentrations in autopsy material from fatal cases after intake of morphine and/or heroin. J Forensic Sci Soc 1988;28:87-94.

14. Ruttenber AJ, Kalter HO, Santinga P. The role of ethanol abuse in the etiology of heroin-related death. J Forensic Sci 1990;35:891-900.

15. Zador D, Sunjic S, Darke S. Heroinrelated deaths in New South Wales, 1992: toxicological findings and circumstances. Med J Aust 1996;164:204-7.

16. Duraković Z. Klinička toksikologija. Zagreb: Grafos; 2000. 


\section{Sažetak}

\section{KOBNA INTOKSIKACIJA ALKOHOLOM I HEROINOM}

U posljednje vrijeme u Splitsko-dalmatinskoj županiji konzumiranje opojnih droga uz alkohol je u porastu. Ovim radom prikazali smo dva slučaja s tri smrtno stradale osobe koje su bile kobne žrtve kombinacije alkohola i heroina. U prvom slučaju, mladi par, u dobi od 30 i 28 godina, pronađen je u automobilu okružen limenkama raznih alkoholnih pića. Dvije šprice nađene su kraj tijela. Žrtve su bili registrirani ovisnici i na programima odvikavanja u organiziranim tretmanima. Drugi slučaj bio je 29-godišnji muškarac pronađen mrtav u napuštenoj kući. Na njegovoj desnoj ruci primijećene su tri svježe ubodne rane, a dvije šprice pronađene su kraj tijela. Nije bio poznat kao ovisnik o drogama, ali je nedavno pokušao samoubojstvo. Karboksihemoglobin nađen je u uzorcima krvi obiju žrtava iz prvog slučaja. Koncentracija je bila $25 \%$, što je moglo pridonijeti njihovoj smrti. U oba opisana slučaja maseni udjel alkohola u krvi bilo je veći od $1.60 \mathrm{~g} \mathrm{~kg}^{-1}$. Toksikološke analize bile su pozitivne na heroin, mekonin, acetaminofen, monoacetil morfin, kodein, noskapin i papaverin. Alkohol, i sam kao depresor respiracije, zajedno s heroinskom smjesom značajno povisuje rizik od nagle smrti kao posljedice zatajenja disanja.

KLJUČCNE RIJEČI: kobno trovanje, intravensko ubrizgavanje, smrt, toksikologija

\section{CORRESPONDING AUTHOR:}

Davorka Sutlović

Department of Pathology and Forensic Medicine

Split University Hospital and School of Medicine

Spinčićeva 1, 21000 Split, Croatia

E-mail:dsutlov@kbsplit.hr 